\title{
Identifying and prioritizing different factors influencing the success of advertisement during the economic depression
}

\author{
Aram Rashidi $^{\mathrm{a}^{*}}$ and Meisam Jafari Eskandari ${ }^{\mathrm{b}}$
}

${ }^{a}$ Department of Progress, Iran University of Science and Technology, Narmak, Iran

${ }^{b}$ Faculty Member of Industrial Engineering Department, Payamnoor, University, Tehran Branch, Tehran, Iran

CHRON I C L E

Article history:

Received July 28, 2013

Received in revised format

20 November 2013

Accepted 4 January 2014

Available online

February 112014

Keywords:

Economic depression

Advertising

Responsiveness

Availability

Customer behavior

\section{Introduction}

During the past few years, the world has faced a financial crisis with serious impact on the world economy. After a decade or more of economic stability, the global economy has faced a period of increasing inflation and falling economic growth (Bahiti et al., 2011; Mansoor \& Jalal, 2011). Part of the reason for economic downturn is that developed countries are passing through the most prolonged period of financial turmoil that most of us can remember (Sufian \& Habibullah, 2010). Obviously, it influenced on financial markets particularly in Europe much more than others, including emerging economies, which are usually considered more vulnerable. Most crises reduce economic growth and

*Corresponding author. Tel: +989126073703

E-mail addresses: aramrashidi230@gmail.com (A. Rashidi)

(C) 2014 Growing Science Ltd. All rights reserved. doi: $10.5267 /$ j.ms 1.2014 .2 .012 
thereby influence the economies of developing countries (Olaniyi \& Olabisi, 2011). The recent financial crisis in the U.S.A, according to many experts, has created one of the greatest crises in the economy after the 1930 crisis and it has been gradually expanded to European countries and the rest of the world (Kohn, 2009). Indeed, the financial crisis, happened in United States and other developed countries, has reduced US exports including raw materials, oil and other natural resources. The pressure on the current account and balance of payments reduced growth rates as well as foreign investment, which, in turn, has increased unemployment (Choudhry et al., 2010), reduced government revenues and eventually falling stock markets in developing countries (Alfaro, 2010).

Despite all the problems created by the US crisis, in fact, a plan to combat the economic downturn may be the best strategy. Some people believe that when we are in a recession economy; there still tremendous opportunities to earn money. As the owner of a small business when we observe market is slack, we may use different opportunities to acquire new customers or to discover the untapped markets of the past (Abu, 2010).

\section{Literature review}

Depression is not a new phenomenon and the world's economies are stagnating several times and have been out of recession. During the deep recession and the economic downturn of 1930, for many years, most European countries as well as US economy were suffered from the consequences of the recession. However, the economic downturn in 2008 has led to fewer losses, for several reasons, including the availability of reliable data and economic statistics and government and private sector information (Berger \& Bouwman, 2013). During the financial crisis of 2007, many of the businesses and banks were bankrupted. Market mortgage crisis and the collapse of the economic system in US economy have created a fluctuation wave (Ripple effect) on the other industrialized economies around the world. The psychological effect of the global economic collapse of the world has also influenced other economies as well (Erkens et al., 2012). However, the economic downturn has also changed the market of adequate iodine intake (Sufian \& Habibullah, 2010). The organizations can use more dynamic and effective advertising in recessions to achieve their silent and thoughtful innovative ideas. Unfortunately, most managers do not know that advertising in depression period may create tremendous opportunities for their companies (Goldfrey \& Dillon, 2007). Table 1 shows the changes in macro level variables such as growth domestic products (GDP) and unemployment rate in members of Organization for Economic Cooperation and Development (OECD) (Gros \& Alcidi, 2010).

\section{Table 1}

Change in macro Variable in OECD countries

\begin{tabular}{lcccccc}
\hline Year & 2004 & 2005 & 2006 & 2007 & 2008 & 2009 \\
\hline Percent change in GDP & 3.2 & 2.7 & 3.1 & 2.7 & 0.6 & -3.5 \\
Percent change in internal demand & 3.3 & 2.9 & 3 & 2.4 & 0.2 & -3.7 \\
Unemployment rate(percent) & 6.8 & 6.6 & 6 & 5.6 & 5.9 & 8.2 \\
\hline
\end{tabular}

The crisis transfer to worldwide, because of two main reasons: The sudden rise in risk aversion and financial market instability were transmitted very quickly (Goldberg \& Dillon, 2007). Moreover, the sudden drop in demand, especially for capital-intensive goods was transmitted into global market. Within Europe, the integration of financial markets and supply chains are even stronger (Abdelbaki, 2010). One of the most important tools of communication and business customers business is advertising. Success and failure of many organizations and companies depend on in the quality of their advertising campaigns (Durra, 2001). Thus, we can conclude that the advertise opens a way to client and sends a message to various types of audiences. If these movements are combined with customers' psychology, art, and taste, with appropriate content and other conditions, it becomes more effective (Larous, 2005). Today, in the world, advertising has become a major industry and business. 
The advertising industry is a tool used by many people. Four challenges could be identified in association with the impact of the recession on consumers' purchasing behavior (Laros \& Steenkamp, 2005; Aliqah et al., 2010), which are decrease disposable income of people, increase prices, reduction in the ability of people to save money and investments and instability and lack of job security. On the other hand, during the recession, companies try to use possible ways to reduce their costs and they are quite reasonable. During this period, all feel that they must maintain their cash rather than spend it (Nistorescu \& Puiu, 2009).

\section{The proposed study}

The proposed study of this paper considers the following hypotheses,

Hypothesis 1: Advertising tools significantly influence on the success of firm's advertisement during the recession.

Hypothesis 2: Visual and structural style significantly influence on the success of firm's advertisement during the recession.

Hypothesis 3: The amount of money spent influences on the success of firm's advertisement during the recession.

Hypothesis 4: Availability influences on the success firm's advertisement during the recession.

Hypothesis 5: Content factors significantly influence on the success of firm's advertisement during the recession.

Hypothesis 6: Responsiveness to the needs of the audience influences on the success firm's advertisement during the recession.

The proposed study of this paper has designed a questionnaire in Likert scale and distributed it among some experts who worked for a dairy producer named Kalle in Iran. There were 185 employees for the unit and the proposed study is determined as follows,

$$
n=\frac{N \times z_{\alpha / 2}^{2} \times p \times q}{\varepsilon^{2} \times(N-1)+z_{\alpha / 2}^{2} \times p \times q},
$$

where $N$ is the population size, $p=1-q$ represents the yes/no categories, $z_{\alpha / 2}$ is CDF of normal distribution and finally $\varepsilon$ is the error term. Since we have $p=0.5, z_{\alpha / 2}=1.96$ and $N=185$, the number of sample size is calculated as $n=105$. Cronbach alpha has been calculated as 0.93 , which is well above the minimum acceptable level. Fig. 1 demonstrates the summary of personal characteristics of the participants.

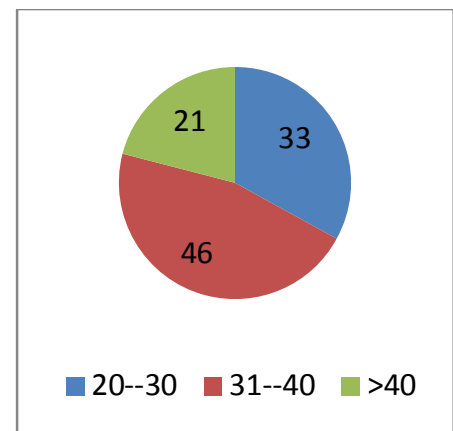

Age

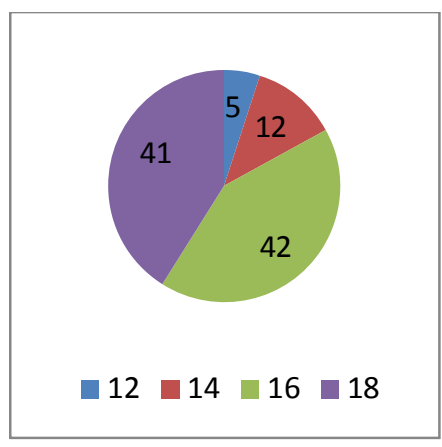

Years of education

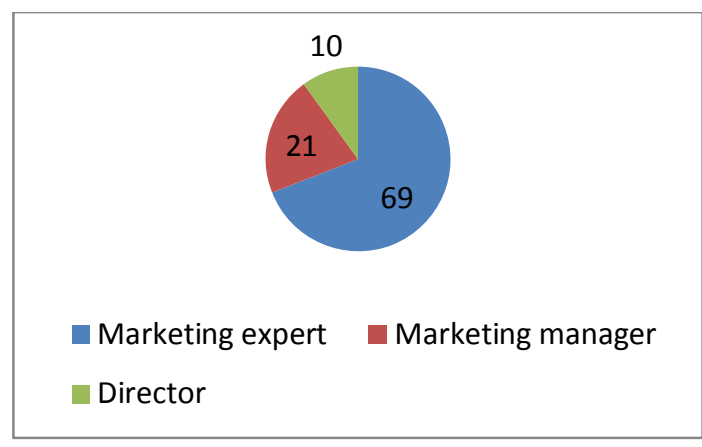

Position

Fig. 1. Personal characteristics of the participants 
In our survey, $78 \%$ of the participants were male and $22 \%$ of them were female. In terms of age, most people who took part in our survey were middle age and maintained some university education. Table 2 demonstrates details of the questions of the survey along with Cronbach alpha for each component.

Table 2

Questions into the questionnaire

\begin{tabular}{|c|c|c|c|}
\hline Variable & Dimension & No of Questions & Cronbach alphas \\
\hline Advertising tools & $\begin{array}{ll}\text { 1. } & \text { Television } \\
\text { 2. } & \text { Radio } \\
\text { 3. } & \text { Board } \\
\text { 4. } & \text { Postcard } \\
\text { 5. } & \text { others }\end{array}$ & 9 & 0.85 \\
\hline Visual and structural style & $\begin{array}{l}\text { 1. Animation } \\
\text { 2. Use of kids \& women } \\
\text { images } \\
\text { 3. differentiation }\end{array}$ & 5 & 0.71 \\
\hline The amount of money spent & $\begin{array}{l}\text { 1. Design cost } \\
\text { 2. Show cost } \\
\text { 3. Promotional cost }\end{array}$ & 6 & 0.84 \\
\hline Availability & $\begin{array}{ll}\text { 1. } & \text { Time } \\
\text { 2. } & \text { Place } \\
\text { 3. } & \text { Tools } \\
\text { 4. } & \text { Price }\end{array}$ & 9 & 0.91 \\
\hline Content factors & $\begin{array}{l}\text { 1. Advantage } \\
\text { 2. Enough information } \\
\text { 3. Address } \\
\text { 4. Price } \\
\text { 5. Place }\end{array}$ & 10 & 0.81 \\
\hline $\begin{array}{l}\text { Responsiveness to the needs of } \\
\text { ustomer }\end{array}$ & 1. customer identification & 3 & 0.95 \\
\hline
\end{tabular}

We have used Kolmogorov-Smirnov test to verify whether the data are normally distributed or not and the results have confirmed that the data indeed follow normal distribution. Therefore, we use Pearson correlation test to examine various hypotheses of the survey. In order to test all hypotheses of the survey, we consider the following,

$$
\left\{\begin{array}{l}
H_{0}: \rho=0 \\
H_{1}: \rho \neq 0
\end{array}\right.
$$

\section{The results}

We now present details of our finding on testing various hypotheses of the survey. Table 3 summarizes the results of different factors on advertisement during the recession.

\section{Table 3}

Results of hypothesis testing

\begin{tabular}{llccc}
\hline Hypothesis & Variable & Pearson correlation & (t-value) & Result \\
\hline 1 & Advertising tools & 0.64 & 5.18 & Confirmed \\
2 & Visual and structural style & 0.45 & 1.25 & Rejected \\
3 & The amount of money spent & 0.46 & 6.21 & Confirmed \\
4 & Availability & 0.42 & 5.15 & Confirmed \\
5 & content factors & 0.51 & 6.32 & Confirmed \\
6 & responsiveness to the needs of customer & 0.62 & 7.12 & Confirmed \\
\hline
\end{tabular}


As we can observe from the results of Table 3, except one case, the second hypothesis, all other hypotheses have been confirmed and we can conclude that advertising tools, the amount of money spent on advertisement, availability, content factors and responsiveness to the customers' needs influence positively on the effectiveness of advertisement during the recession time. However, we do not have enough evidence to believe that visual items could have any meaningful impact on advertisement. Next, we use Freedman test to prioritize the effects of various factors shown in Table 4 as follows,

Table 4

The results of ranking different factors based on Freedman test

\begin{tabular}{llc}
\hline Rank & Factor & Mean rank \\
\hline 1 & Responsiveness to the needs of customer & 16.01 \\
2 & Advertising tools & 15.33 \\
3 & Content factors & 14.06 \\
4 & Amount of money spent & 13.85 \\
5 & Availability & 13.52 \\
\hline
\end{tabular}

As we can observe from the results of Table 4, meeting customers' needs is the first priority during the recession followed by using appropriate advertising tools, content factors, the amount of money spent on advertisement and availability.

\section{Conclusions}

In this paper, we have presented an empirical investigation to study the effects of advertisement on sales improvement during the recession time. Using a Likert based questionnaire, the study has chosen some employees who worked for a dairy producer in Iran and performed the survey. The results have indicated that it is important to determine customers' necessary requirement before taking any advertisement actions. In addition, firms need to choose appropriate methods for advertisement to penetrate the market, carefully. Nevertheless, sales figures could be improved by spending necessary funds in order to attract more people.

\section{Acknowledgement}

The authors would like to thank the anonymous referees for constructive comments on earlier version of this paper.

\section{References}

Abdelbaki, H. H. (2010). Assessing the impact of the global financial crisis on GCC countries. Journal of Business \& Economics Research (JBER), 8(2).

Alfaro, L., \& Chen, M. X. (2010). Surviving the global financial crisis: foreign direct investment and establishment performance. Harvard Business School BGIE Unit Working Paper, (10-110).

Aliqah, A., Mohammad-AL-RFOU, K., \& Nahar, A. (2010). The impact of global financial crisis on consumer behavior in Jordan. European Journal of Social Sciences, 12(4), 618-623.

Bahiti, R., Perri, R. S., \& Babasuli, J. (2011). Impact of the Latest Financial Crises on a Bank-Based Financial System: Case of Albania. Romanian Economic Journal, 14(39).

Berger, A. N., \& Bouwman, C. H. (2013). How does capital affect bank performance during financial crises?. Journal of Financial Economics, 109(1), 146-176.

Choudhry, M. T., Marelli, E., \& Signorelli, M. (2010, March). Financial crises and labour market performance. In International Atlantic Economic Conference, Prague (pp. 24-27). 
Erkens, D. H., Hung, M., \& Matos, P. (2012). Corporate governance in the 2007-2008 financial crisis: Evidence from financial institutions worldwide. Journal of Corporate Finance, 18(2), 389411.

Goldberg, L., \& Dillon, E. W. (2007). Why a dollar depreciation may not close the US trade deficit. Federal Reserve Bank of New York Current Issues in Economics and Finance, 13(5), 1-7.

Gros, D., \& Alcidi, C. (2010). The impact of the financial crisis on the real economy. Intereconomics, 45(1), 4-20.

Kohn, D. (2009, April). Policies to bring us out of the financial crisis and recession. In Speech at Forum on Great Decisions in the Economics Crisis(Vol. 3).

Laros, F. J., \& Steenkamp, J. B. E. (2005). Emotions in consumer behavior: a hierarchical approach. Journal of business Research, 58(10), 1437-1445.

Mansoor, D., \& Jalal, A. (2011). The global business crisis and consumer behavior: Kingdom of Bahrain as a case study. International Journal of Business \& Management, 6(1).

Nistorescu, T., \& Puiu, S. (2009). Marketing strategies used in crisis-case study. MPRA Paper, 17743.

Olaniyi, T. A., \& Olabisi, O. Y. (2011). Causes and impacts of global financial crisis on the performance of Nigerian banks (a case study of selected banks). E3 Journal of Business Management and Economics., 2(4), 164-170.

Sufian, F., \& Habibullah, M. S. (2010). Assessing the impact of financial crisis on bank performance: Empirical evidence from Indonesia. ASEAN Economic Bulletin, 27(3), 245-262. 